\title{
Advances in understanding the interaction between the gut microbiota and adaptive mucosal immune responses Andrew S Neish ${ }^{1 *}$ and Timothy L Denning ${ }^{2}$
}

\author{
Addresses: ${ }^{1}$ Department of Pathology, Epithelial Pathobiology Unit, Emory University School of Medicine, 105-F Whitehead Medical Research \\ Building, Atlanta, GA 30322, USA; ${ }^{2}$ Department of Pediatrics, Emory University School of Medicine, 105-R Whitehead Medical Research Building, \\ Atlanta, GA 30322, USA \\ * Corresponding author: Andrew S Neish (aneish@emory.edu) \\ FI000 Biology Reports 2010, 2:27 (doi:10.34I0/B2-27)
}

The electronic version of this article is the complete one and can be found at: http://fl000.com/reports/biology/content/2/27

\begin{abstract}
Commensal gut bacteria are necessary for the complete development of mucosal innate and adaptive immunity and thus may influence intestinal and systemic immune disorders. Recent work has advanced our understanding of this association by identification of a single taxon of the murine microbiota which can stimulate T-cell development and differentiation. It is hoped that further characterization of the mechanisms involved will enable targeted manipulation of the microbiotaimmune system relationship.
\end{abstract}

\section{Introduction and context}

Eukaryotes have been living in intimate contact with prokaryotes throughout the course of evolution. Especially in the context of the gut, the host has developed highly conserved interrelated systems to protect itself from pathogenic attack whilst allowing beneficial microbes - symbionts - to thrive. Past study of primordial immune mechanisms conserved in nonvertebrates has richly informed our understanding of the activation (and suppression) of innate immune networks. As adaptive immunity is restricted to vertebrates, our appreciation of how gut commensal communities interact with mucosal and systemic adaptive immunity is less understood.

The gut/mucosal arm of the adaptive immune system provides humoral and cell-mediated immunity against ingested antigens and luminal organisms and is localized predominantly in the small bowel. Effector lymphocytes are diffusely distributed in the lamina propria (LP) or in isolated lymphoid follicles or are organized into discrete structures termed Peyer's patches, which are essentially mucosal lymph nodes overlaid with a specialized epithelial cell type, the $\mathrm{M}$ cell, which possesses the endocytic machinery for uptake of particulate antigens from the gut lumen. Members of the normal flora, along with non-viable particulate antigens and all-too-viable pathogens, are continually being sampled by the $\mathrm{M}$ cells and perhaps other portals for processing by local dendritic cells or macrophages and subsequent education and activation of effector B and T cells [1].

The microbiota is clearly involved in the anatomic and functional development of mucosal immunity [2]. Peyer's patches are grossly hypoplastic and IgA responses are reduced in germ-free animals. It is also known that germ-free animals have reduced total CD4 T-cell populations and an inappropriate balance of $\mathrm{T}_{\mathrm{H}}$-cell subsets [3], which can be moderated within weeks upon colonization with a representative member of the normal flora (Bacteroides fragilis) [4] via dendritic cell recognition of a specific polysaccharide (polysaccharide A) component of $B$. fragilis [5]. Interestingly, the intestinal LP in healthy animals was shown to be a major location of a unique population of interleukin17-producing $\mathrm{CD}^{+} \mathrm{T}$ cells $\left(\mathrm{T}_{\mathrm{H}} 17\right.$ cells) distinct from $\mathrm{T}_{\mathrm{H}} 1$ - or $\mathrm{T}_{\mathrm{H}}$ 2-cell lineages $[6,7]$. This work has spawned an explosion of interest in the development and functions of $\mathrm{T}_{\mathrm{H}} 17$ cells in health and disease, especially in the gastrointestinal tract. While $\mathrm{T}_{\mathrm{H}} 17$ cells are increased in 
inflamed intestinal tissue, it remains unclear whether these cells are pathogenic or protective during intestinal inflammation; additionally, the mechanisms driving their development and differentiation are now only beginning to emerge [8].

\section{Major recent advances}

Analyses in germ-free mice as well as antibiotic-treated conventional mice have shown that the intestinal microbiota can drive the development of $\mathrm{T}_{\mathrm{H}} 17$ cells in the murine intestine $[9,10]$. The mechanism by which the intestinal microbiota induces $\mathrm{T}_{\mathrm{H}} 17$ cells is not via the classical Toll-like receptor adaptor molecules MyD88 or Trif, but potentially via ATP generation. To begin to probe which components of the diverse microbiota may preferentially induce $\mathrm{T}_{\mathrm{H}} 17$ cells, Ivanov et al. [11] performed an immunophenotypic comparison of the same mouse strain (B6) obtained from two commercial vendors (Taconic, Tarrytown, NY, USA, and The Jackson Laboratory, Bar Harbor, ME, USA) and found that the mice from The Jackson Laboratory showed a remarkable lack of $\mathrm{T}_{\mathrm{H}} 17$ cells in the LP. Interestingly, transfer of Taconic flora (by direct gavage of fecal flora or by cohousing) to the mice from The Jackson Laboratory resulted in the induction of $L P T_{H} 17$ cells, indicating a stark difference in the immunostimulatory potential of the distinct microbiota. This observation has been further developed in two recent papers by Ivanov et al. [11] and Gaboriau-Routhiau et al. [12], both reaching the surprising conclusion that T-cell development in general and $\mathrm{T}_{\mathrm{H}} 17$ differentiation in particular are largely induced by the action of a single (or at least limited) number of bacterial taxa.

In the paper of Ivanov and colleagues [11], the authors exploited the Phylochip (Affymetrix, Santa Clara, CA, USA) - a 16s ribosomal microarray platform that serves as a massive $(300,000$ probe) parallel survey of microbial taxa - and identified segmented filamentous bacteria (SFB), a non-culturable spore-forming Grampositive Clostridia-related species present in B6 mice from Taconic, but not The Jackson Laboratory. With the use of germ-free mice or Jackson Laboratory-sourced mice colonized ('conventionalized') with SFB, this group studied $\mathrm{T}_{\mathrm{H}} 17$ differentiation in LP lymphocyte populations and expression profiling to show that SFB could recapitulate the inductive effects of the intact Taconic microbiota [11]. An independent group headed by Gaboriau-Routhiau also used an expression profiling approach to characterize host responses of germ-free mice conventionalized with normal murine microbiota and found distinct patterns of innate (inflammatory) gene expression and adaptive immune stimulation (LP T-cell maturation). This signature of normal immune development was not induced by candidate monoassociated microbiota representatives or complex normal human microflora [12]; however, the host immune response pattern to normal murine microflora could be recapitulated by SFB as a mono-associated strain, further implicating this taxon as a primary driver of adaptive immune development (Figure 1).

\section{Future directions}

Though intriguing, these findings raise many important questions. SFB are not cultivable and must be maintained in monocultured mice [13] and introduced to other mice by cohousing. Thus, further characterization of the SFB is obviously necessary; sequencing of their genome will be eagerly anticipated, as will be culture techniques that may allow them to be more readily introduced into test systems. It will be interesting to see what other taxa can mediate the immune stimulatory phenotype and whether there is a specific ligand (microbial-associated molecular pattern, or MAMP) present on a subset (perhaps a very limited subset) of commensals. Conversely, what are the specific receptors that the host uses to perceive this functional class of

Figure I. Intestinal microflora modulates mucosal immune responses

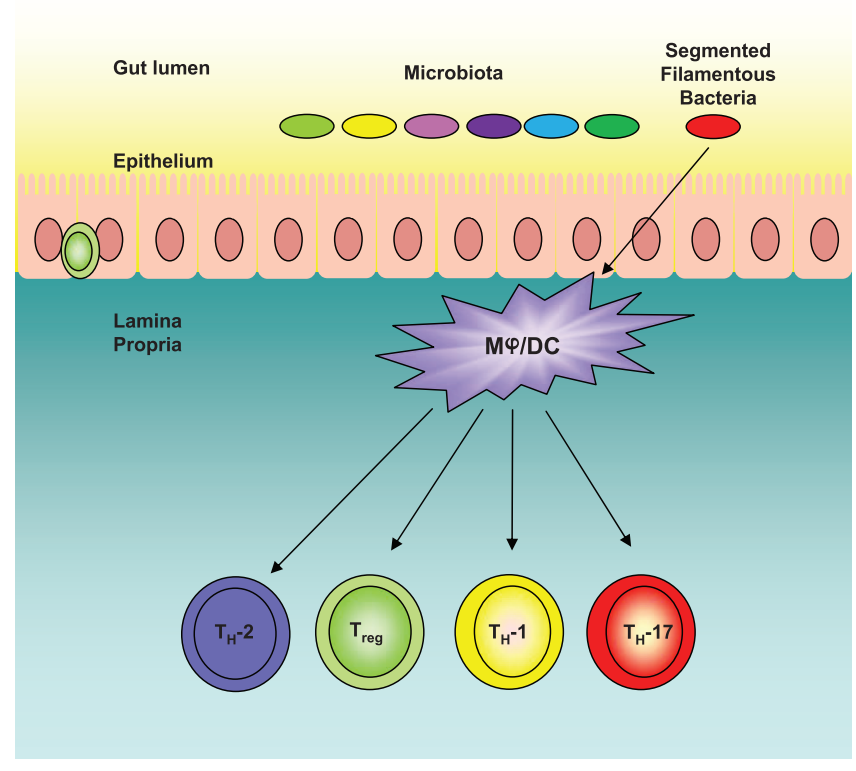

Recent reports implicate segmented filamentous bacteria (SFB) as the major component of the commensal microbiota which modulates mucosal T-cell development/responses. SFB, in particular, are potent inducers of $T_{H} I 7$ differentiation. The mechanisms by which these bacteria direct T-cell differentiation are poorly understood at present but may include direct interactions with intestinal epithelial cells, dendritic cells (DC), or macrophages $(M \varphi)$ (or all three). $\mathrm{T}_{\text {reg, }}$ regulatory $\mathrm{T}$ cells. 
microbe and which cell types in specific regions of the intestine sense SFB in order to direct adaptive immunity? In directing $\mathrm{T}_{\mathrm{H}^{-}}$-cell differentiation, do SFB and other commensal bacteria directly interact with LP dendritic cells and macrophages that augment $\mathrm{T}_{\mathrm{H}} 17$ and $\mathrm{T}_{\text {reg }}$ (regulatory $\mathrm{T}$ ) responses [14-17] or do they induce changes in intestinal epithelial cells that in turn imprint dendritic cells with this capacity [18]? Are SFB invasive to epithelial cells? It is also clearly important to identify the human SFB equivalent(s). As potential targets for modification, SFB may offer a clue to the identification of bacteria that could be added to (or suppressed from) the microflora to accrue benefits such as altered immune regulation relevant to human disorders such as inflammatory bowel disease and systemic autoimmunity.

\section{Abbreviations}

LP, lamina propria; SFB, segmented filamentous bacteria; $\mathrm{T}_{\mathrm{H}} 17$, interleukin-17-producing $\mathrm{CD}^{+} \mathrm{T}$ (cell).

\section{Competing interests}

The authors declare that they have no competing interests.

\section{Acknowledgments}

The laboratory of ASN is supported by the National Institutes of Health (DK71604 and AI64462).

\section{References}

I. Mowat AM: Anatomical basis of tolerance and immunity to intestinal antigens. Nat Rev Immunol 2003, 3:33I-4I.

2. Slack E, Hapfelmeier S, Stecher B, Velykoredko $Y$, Stoel M, Lawson MA, Geuking MB, Beutler B, Tedder TF, Hardt WD, Bercik P, Verdu EF, McCoy KD, Macpherson AJ: Innate and adaptive immunity cooperate flexibly to maintain hostmicrobiota mutualism. Science 2009, 325:617-20.

FI000 Factor 6.5 Must Read

Evaluated by Kiyoshi Takeda 19 Aug 2009, Mauro Teixeira 26 Aug 2009, Hannah Carey 02 Sep 2009

3. Macpherson AJ, Harris NL: Interactions between commensal intestinal bacteria and the immune system. Nat Rev Immunol 2004, 4:478-85.

4. Mazmanian SK, Liu CH, Tzianabos AO, Kasper DL: An immunomodulatory molecule of symbiotic bacteria directs maturation of the host immune system. Cell 2005, 122:107-18.

FI000 Factor 10.6 Exceptional

Evaluated by Joern Piel 25 Jul 2005, Torben Lund 29 Jul 2005, Emanuela Handman 04 Aug 2005, Ben Lugtenberg II Aug 2005 , Rino Rappuoli 26 Aug 2005, Shiv Pillai 19 Oct 2005, Richard Grencis 09 Nov 2005, Lora Hooper 15 Dec 2005

5. Mazmanian SK, Round JL, Kasper DL: A microbial symbiosis factor prevents intestinal inflammatory disease. Nature 2008, 453:620-5.

FI000 Factor 6.8 Must Read

Evaluated by Victor Nizet 09 Jun 2008, Christopher Thanos 16 Jun 2008, Richard Grencis 0 I Jul 2008, Alan Landay II Jul 2008

6. Harrington LE, Hatton RD, Mangan PR, Turner H, Murphy TL, Murphy KM, Weaver CT: Interleukin 17-producing CD4+ effector $T$ cells develop via a lineage distinct from the T helper type I and 2 lineages. Nat Immunol 2005, 6: I I 23-32.

FI000 Factor 8.5 Exceptional

Evaluated by Christopher Karp 04 Nov 2005, Richard Grencis 04 Nov 2005, Marsha Wills-Karp 08 Nov 2005, Dan Conrad 18 Nov 2005, Marie Kosco-Vilbois 28 Nov 2005

7. Ivanov II, McKenzie BS, Zhou L, Tadokoro CE, Lepelley A, Lafaille J], Cua DJ, Littman DR: The orphan nuclear receptor RORgammat directs the differentiation program of proinflammatory IL-17+ T helper cells. Cell 2006, I26:1 I21-33.

FI000 Factor II.3 Exceptional

Evaluated by Caetano Reis e Sousa 02 Oct 2006, Christopher A. Hunter 05 Oct 2006, Casey Weaver 09 Oct 2006, Richard Williams 18 Oct 2006, Dale Umetsu 02 Nov 2006, Klaus Ley 07 Nov 2006, Mercedes Rincon 17 Nov 2006, Rachel Caspi II Dec 2006, Fraydoon Rastinejad I4 Dec 2006, Astar Winoto 02 Jan 2007

8. Weaver CT, Hatton RD, Mangan PR, Harrington LE: IL-I7 family cytokines and the expanding diversity of effector $T$ cell lineages. Annu Rev Immunol 2007, 25:82 I-52.

9. Atarashi K, Nishimura J, Shima T, Umesaki Y, Yamamoto M, Onoue M, Yagita H, Ishii N, Evans R, Honda K, Takeda K: ATP drives lamina propria $\mathbf{T}(\mathrm{H}) 17$ cell differentiation. Nature 2008, 455:808- 12.

FI000 Factor 8.4 Exceptional

Evaluated by Torben Lund 17 Oct 2008, Klaus Ley 24 Oct 2008, Steve Ward 28 Oct 2008, Ivana Novak 29 Oct 2008, Dale Umetsu 09 Jan 2009

10. Ivanov II, Frutos Rde L, Manel N, Yoshinaga K, Rifkin DB, Sartor RB, Finlay BB, Littman DR: Specific microbiota direct the differentiation of IL-17-producing T-helper cells in the mucosa of the small intestine. Cell Host Microbe 2008, 4:337-49.

FI000 Factor 8.I Exceptional

Evaluated by Klaus Ley 24 Oct 2008, David Underhill 30 Oct 2008, Mark Atkinson II Aug 2009

II. Ivanov II, Atarashi K, Manel N, Brodie EL, Shima T, Karaoz U, Wei D, Goldfarb KC, Santee CA, Lynch SV, Tanoue T, Imaoka A, Itoh K, Takeda K, Umesaki Y, Honda K, Littman DR: Induction of intestinal ThI7 cells by segmented filamentous bacteria. Cell 2009, 139:1-14.

FI000 Factor 9.8 Exceptional

Evaluated by Dale Umetsu 27 Oct 2009, David Alpers 05 Nov 2009, Anuradha Ray 12 Feb 2010

12. Gaboriau-Routhiau V, Rakotobe S, Lécuyer E, Mulder I, Lan A Bridonneau C, Rochet V, Pisi A, De Paepe M, Brandi G, Eberl G, Snel J, Kelly $D$, Cerf-Bensussan N: The key role of segmented filamentous bacteria in the coordinated maturation of gut helper T cell responses. Immunity 2009, 31:677-89.

FI000 Factor 3.0 Recommended

Evaluated by Denise M Monack 10 Dec 2009

13. Klaasen HL, Koopman JP, Van den Brink ME, Van Wezel HP, Beynen AC: Mono-association of mice with non-cultivable, intestinal, segmented, filamentous bacteria. Arch Microbiol 1991, I56:|48-51.

14. Denning TL, Wang YC, Patel SR, Williams IR, Pulendran B: Lamina propria macrophages and dendritic cells differentially induce regulatory and interleukin 17-producing $\mathrm{T}$ cell responses. Nat Immunol 2007, 8:1086-94.

FI000 Factor 6.7 Must Read

Evaluated by Eric Denkers 03 Oct 2007, Maria Rescigno 03 Oct 2007, Luciano Adorini 19 Nov 2007, Reina Mebius 17 Jan 2008

15. Coombes JL, Siddiqui KR, Arancibia-Carcamo CV, Hall J, Sun CM, Belkaid $Y$, Powrie F: A functionally specialized population of mucosal CDI 03+ DCs induces Foxp3+ regulatory T cells via a TGF-\{beta\}- and retinoic acid-dependent mechanism. J Exp Med 2007, 204: 1737-9. 
16. Hall JA, Bouladoux N, Sun CM, Wohlfert EA, Blank RB, Zhu Q, Grigg ME, Berzofsky JA, Belkaid Y: Commensal DNA limits regulatory $T$ cell conversion and is a natural adjuvant of intestinal immune responses. Immunity 2008, 29:637-49.

FI000 Factor 6.0 Must Read

Evaluated by Padmini Salgame 29 Oct 2008

17. Sun CM, Hall JA, Blank RB, Bouladoux N, Oukka M, Mora JR, Belkaid $Y$ : Small intestine lamina propria dendritic cells promote de novo generation of Foxp3 $\mathrm{T}$ reg cells via retinoic acid. J Exp Med 2007, 204:1775-85.

FI000 Factor 6.0 Must Read

Evaluated by Arthur Hurwitz 02 Jan 2008

18. Iliev ID, Mileti E, Matteoli G, Chieppa M, Rescigno M: Intestinal epithelial cells promote colitis-protective regulatory $\mathrm{T}$-cell differentiation through dendritic cell conditioning. Mucosal Immunol 2009, 2:340-50. 